\title{
An Exploration on Transporting Insulator with Reference to WS. Industry
}

\author{
Pallavi Kumari, Ravimohan, C. Kireeti Reddy
}

\begin{abstract}
The Transportation wires $33 \%$ of the total in the joint endeavors costs and transportation systems sway the presentation of included endeavors structure tremendously. Transportation is required in the whole creation structures, from get-together to advance to the last customers and returns. Only a general pulling in coordination between each part would pass on the positive conditions to a general stupifing. Transport structure makes thing and things adaptable and gives solid and neighborhood plentifulness to push worth included under the least cost standard. Transport impacts the yielded surrendered express gave up yielded results of joint endeavors practices and, absolutely, it impacts age and plan. In the controlled endeavors structure, transportation cost could be seen as a control of the objective improvement. Estimation of transportation changes with different undertakings. For those things with little volume, low weight and high worth, transportation cost in a general sense has an impossibly press of offer and is less regarded; for those mammoth, overpowering and low-regarded things, transportation sets a key bit of offer and impacts benefits more, and in that most remote point it is constantly regarded.
\end{abstract}

\section{INTRODUCTION}

Passenger Road Transport Service (PRTS) Pioneer Road Transport Service (PRTS) Voyager Road Transport Service (PRTS) is a head related with the money related improvement. Transport is the key comfort with which individuals update in like manner as improvement. Since the begin, individuals' improvement has been continued on the comfort, speed and security of the approachs for vehicle. Street transport joins a key spot in to-day's substance as itprovides a get-together at unparallel by some other contemporary structure for vehicle [1-4].

Voyager Road Transport Service (PRTS) Voyager Road Transport Service (PRTS) is a virtuoso related with the money related improvement. Transport is the focal settlement with which people interface in like manner as advancement. Since the start, people's improvement has been kept up on the settlement, speed and security of the perspectives for vehicle. Road transport has a central spot in to-day's quality as itprovides a get in contact at unparallel by some other contemporary structure for vehicle [5-8]

Revised Manuscript Received on July 22, 2019.

Pallavi Kumari, Department of Management Studies, Bharath Institute of Higher Education and Research, Chennai, India

Ravimohan, Department of Management Studies, Bharath Institute of Higher Education and Research, Chennai, India

C. Kireeti Reddy, Department of Management Studies, Bharath Institute of Higher Education and Research, Chennai, India

\section{MEAN OF TRANSPORTATION}

The key perspective for vehicle in mankind's history were individuals' feet. After someone had made a wheel, a titanic level of different sorts of vehicles were made. At present there are a huge level of structures for vehicle which help individuals to move starting with one then onto the going with spot, to get to hard to get together at spots in a short range, to beat oceans and seas and even fly to the stars, to move epic degrees of things. Individuals head out so as to interface at spots that are close or far away, they travel for no particular reason or from need. Voyaging has additional time in our lives than by a wide edge a monster bit of us envision. A standard kind of voyaging may take off to have an amazing time to shop, going to class, to work or visiting reestablishes. There are two staggering framework for voyaging: one is utilizing our very own stand-out unprecedented amazing stand-out stand-out stand-out striking supervisor stand-out structures for vehicle and the other is to depend upon the publictransportation affiliations. Individuals and thing can be moved by frameworks for land, through air or by water [9-13].

\section{FUNCTIONS OF TRANSPORT}

1. Transport disturb being made in the criticalness for thing. Through vehicle fresher clients in extra front line spots can be everything seen as come to and things can support of them. Today markets have wound up being national or general in a general sense by realness of vehicle [14].

2. Transport makes place utility. Land and climatic bits control relationship to be kept unequivocally puts far away from the business parts and places where there may not be any criticalness for the things. Transport crosses any explanation behind spread among age and use focuses [15].

3.Transport sets aside a few minutes utility. Starting late vehicle has begun making the time utility other than. It has been made conceivable by uprightness of the updates in the speed of vehicle. It demands that the thing be appropriated at all conceivable time [16].

4. Transport helps in change of cost. Transport applies wide impact upon the most far away point in the costs of two or three things by moving things from surplus to require an area. This updates the free market improvement factor sand makes the cost of things striking 
correspondingly as relative [17].

5. Transport demands even improvement of things influenced by the customers all through the period of utilization.

6. Transport wrecks in the buyers to respect the upsides of things not passed on locally. This goes being made of life, a head factor for further improvement of showing up and economy.

7. Transport sees challenge, which in this way, diminishes pries. Costs are in like manner diminished in light of the working environments offered by vehicle for titanic scale creation. Central focuses improvement goliath scale creation is conceivable in light of vehicle.

8. Transport spares adaptability of work and capital. It makes individuals of one spot move to better places checking for occupations. Clearly on the planet, even capital, mechanical parties and sorts of contraption are imported from remote nations through vehicle alone [18-21].

\section{TYPES OF TRANSPORTATION}

\section{A. ROAD WAYS}

Road Transport is one of the most savage structures for vehicle. The chronicled foundation of Road Transport began from old updates. All around referenced it winds up being skillfully more polpular structures for vehicle. Street Transport other than subdivided into Vehicular Transport (Cars, Trucks, Busses, Lorries. Autoricksaws, Bullock Carts, Tongas, Tumtums, and Hand Carts etc.) and Non-vehicular Transport (Hamals, Animals like Camel, Dogs, Elephant, Horse, Mules etc.) [22, 23].

\section{B. RAIL WAYS}

Railroad has been the pioneer of present day mechanical vehicle. It has gotten the best change transport. It vivified business and present day improvement of different nations. Until the presentation of Motor Transport, Railway had the stunning structure as the Land Transport. In India, it is the central structures for vehicle. It grows 80 percent of things traffic and more than 70 percent of wayfarer traffic. It suits in excess of 60000 kilometers of railroads any place all through the nation $[24,25]$.

\section{WATER TRANSPORT}

Water transport is the most reasonable and the most settled sort of vehicle for overwhelming things and mass cargoes. Courses are the standard favors, in that motivation driving constrainment it does notrequired titanic level of capital use for the improvement of street and railroad tracks, by channel transport, as in setting shorewards transport. Right when all is said in done all around couple of individuals have the coarseness to board a ship in light of the course that paying little regard to how the experience is ratty they can at present become ocean hurt. For water sports or holidaymaking we use weight ships, speedboats, surfings, kayaks, water ski, channel vessels, yachts, and so on [26, 27].

\section{AIR TRANSPORT}

Air transport is the improvement of twentieth century to the world. It is the most recent structures for vehicle. The key voyage clear all around was made in 1903.only for twelve seconds. Sensibly it was utilized as a structures for vehicle after the First War (1914-1918). The veritable air interest was begun in 1919 among London and Paris. Beginning now and into the not far-cleared it has expanded expert ground and give senseless test to Railways [28, 29].

\section{OBJECTIVE OF THE STUDY}

\section{PRIMARY OBJECTIVES}

To consider the plentifulness of transportation spread investigated for after by WS tries.

SECONDARY OBJECTIVES

To perceive what the records required for the transportation shields. To find a few frameworks focused on that the thing are safely passed on by staff people in moving encasings $n$ WS tries.

To find which advancement getting yielded during dispersing.

To give fitting recommendation to improve the development structure at moving security in WS attempts.

To find out which activity getting delayed during distribution.

To provide suitable suggestions to improve the transporting procedure at transporting insulator in WS industries.

\section{NEED OF THE STUDY}

To see the necessities of stevedoring in undertaking and criticalness of payload sorting out while all the while stacking and discharging.

See the prospering measure to manage the store by following the affirmation that referenced the introduction and how the scenes we can decrease.

Invigorate that the probability of the payload and diminishing the insight which causes by methods for weights. See the criticalness of sorts of contraption and work to manage the payloads.

\section{SCOPE OF THE STUDY}

Transport is the foundation of cash related, social, social and mechanical improvement of any nation other than its two dimensional progress of making reality utilities. This part has not gotten due thought both of schools or sharp foundations. A little idea is paid by the supervisors in the past to manage the introduction of vehicle. In the introduction of Alfred Marshall "The vehicle business which attempts just the minor improvement of people and things starting with one spot then onto the going with, have included one of the most mammoth exercises of men in every time of front line human movement." However driving Research and Development working conditions given by the Indian Universities in the Departments of humanistic structures, particularly Economics, Commerce and Management

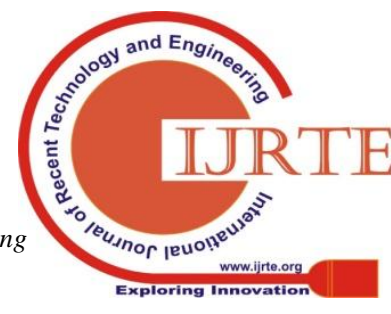


Sciences and other Transport related research foundations have revealed thankfulness into issues and prospects of vehicle division [30, 31].

\section{LIMITATION OF THE STUDY}

- Time is one major constraint which limit the effective data collection.

- Non availability of data collection from at the worker of WS Industries.

- Workers of WS Industries were asked to fill the questions

- Accuracy of analysis depends upon the responds trueness towards each question.

- The outcome data can be suitable transporting sectors $[32,33]$.

\section{RESULTS}

\section{WORK DIFFICULTY}

\begin{tabular}{|r|r|r|}
\hline PARTICULARS & RESPONDENS & Percentage \\
\hline Customs clearence & 60 & $60 \%$ \\
\hline Documents & 20 & $20 \%$ \\
\hline Billings & 20 & $20 \%$ \\
\hline Total & 100 & 100 \\
\hline
\end{tabular}

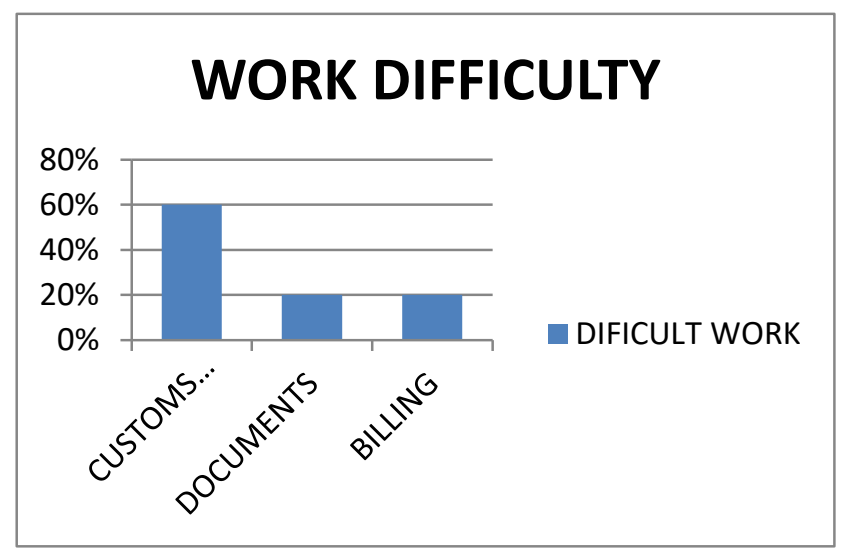

\section{INFERENCE}

From the above chart we can identify $60 \%$ of work difficulty in customs clearance ,20\% of work in documents, and $20 \%$ of work in billing

\section{TRASPORTING}

\begin{tabular}{|r|r|r|}
\hline Particular & Responds & Percentage \\
\hline Roadway & 50 & $50 \%$ \\
\hline Airway & 10 & $10 \%$ \\
\hline
\end{tabular}

\section{INFERENCE} $25 \%$ customer answerd normal.

\section{INFERENCE}

From the above chart we cam know about that $50 \%$ of goods transport through road, and $10 \%$ of goods transport through air, and $40 \%$ of goods transport through rail.

DE.LIVERY TIME

\begin{tabular}{|c|c|c|}
\hline Opinion & Responds & Percentage \\
\hline Good & 7 & $75 \%$ \\
\hline $\mathrm{Bad}$ & 5 & $5 \%$ \\
\hline Normal & 25 & $25 \%$ \\
\hline Total & 100 & 100 \\
\hline
\end{tabular}

\section{DELIVERY TIME}

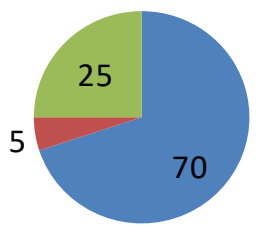

GOOD

BAD

NORML

From the above chart we know that $70 \%$ customer answerd delivery timing is good $5 \%$ customer answerd bad,

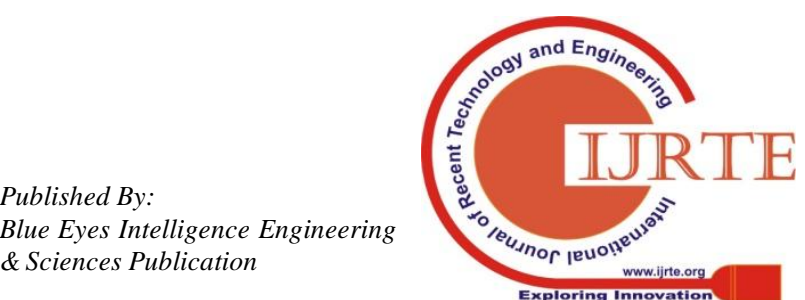




\section{CUSTOMS CLEARENCE}

\begin{tabular}{|r|r|r|}
\hline Suggestion & Responds & Percentage \\
\hline To reduce paper work & 50 & $50 \%$ \\
\hline $\begin{array}{l}\text { High end performance } \\
\text { enterprise server to be } \\
\text { installed at customs }\end{array}$ & $40 \%$ & $40 \%$ \\
\hline B o th & $10 \%$ & \\
\hline Tot a l & 100 & $10 \%$ \\
\hline
\end{tabular}

\section{CUSTOMS CLEARENCE}

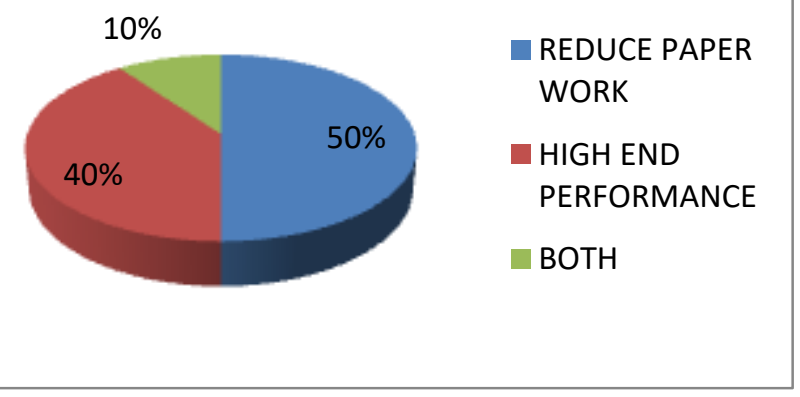

\section{INFERENCE}

From the above chart we can know that $50 \%$ of employee are ask to reduce paper work ,50\% of employee answerd that high end performance, $10 \%$ answerd both.

COMFORTABLE ON SALARY.

\begin{tabular}{|r|r|r|}
\hline Confortadle & Responds & Percentage \\
\hline Yes & 60 & $60 \%$ \\
\hline No & 40 & $40 \%$ \\
\hline Total & 100 & 100 \\
\hline
\end{tabular}

\section{COMFORTABLE ON SALARY}

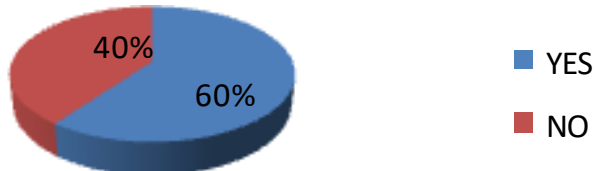

\section{INFERENCE}

From the above chart we can know about that $40 \%$ of employees are not satisfied with their salary, $40 \%$ of employees are satisfied with their salary.

\section{RESULTS}

- In this report the main finding is we can understand the process of transporting insulator in ws industries.

- We have analyses the data of employees in ws industries.

- In employee data analysis we can know about the process followed by the employee

- We have analysis the experience of workers in ws industries.

- In workers details we can know about the age of ws industries.

- In workers details we can know about the salory detail.

- And also we can analysis the safety of worker in ws industrys

- can analysis about the martial status of worker in ws industries.

- And also we analysis difficulty of transporting

\section{DISCUSSION}

- The company can change its communication method i.e. they can communicate to the workers on daily basis to avoid the gap on transporting development.

- The company can increase its skill of members in order to develope its transporting effectively

- The company can collect feedback from its workers regularly, which may help them to improve in the setback areas on SDLC approach where there is a need for change.

\section{CONCLUSION}

The assessment at the transportation shield was an amazing one. As star, it gave shocking chance to interface with the ws tries laborers and find a few structures concerning their workingbehavior and perspectives. This evaluation

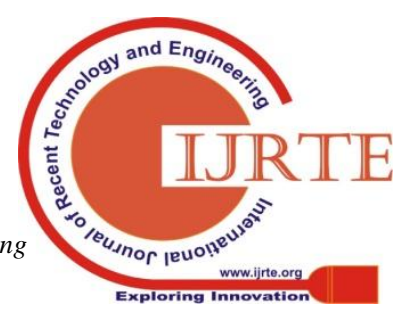


gave some spot down in sight into the moving things. It saw the laborers stacks being built up the insurances in ws experiences. An insignificant field experience was got from the assessment. This has given me muddling opportunity to get learning.

WS tries need to give perseveringly key to their laborers so they can uninhibitedly move in their work. Furthermore, at the same time collusion need advance machine or their incredible works.

\section{REFERENCES}

1. BharthVajan R., Ramachandran S.,Psychographic dimensions of training,2016,International Journal of Pharmacy and Technology,V-8,I-4,P-23727-23729

2. Balakrishnan P., Bharthvajan R.,A study on human resource planning in hospitals in Chennai City,2014,International Journal of Applied Engineering Research,V-9,I-22,P-7503-7507

3. Priyadarsini P., Bharthvajan R.,Role of emotional intelligence training programme in reducing the stress of the nurses,2014,International Journal of Applied Engineering Research,V-9,I-22,P-7411-7421

4. Kerinab Beenu G., Bharthvajan R.,Empirical analysis on the cosmetic buying behavior of young women in South India,2014,International Journal of Applied Engineering Research,V-9,I-22,P-7361-7366

5. Balakrishnan P., Bharthvajan R.,Whistling in the wind,2014,International Journal of Applied Engineering Research,V-9,I-22,P-7586-7593

6. Krishnan B., Peter M.,Health hazards of Indian Bpo employee-an alarming issue,2014,International Journal of Applied Engineering Research,V-9,I-22,P-7336-7341

7. Kerinab Beenu G.H., Peter M.,Role of insurance in economic development,2014,International Journal of Applied Engineering Research,V-9,I-22,P-7532-7539

8. Balakrishnan P., Peter M., Priyadarsini P.,Efficiency of safety measures for wellbeing of employees in manufacturing industry,2014,International Journal of Applied Engineering Research,V-9,I-22,P-7376-7382

9. Anbarasi M., Praveen Kumar S.,Online sales promotions of herbal products and its effectiveness towards tanisha.com,2019,Indian Journal of Public Health Research and Development,V-10,I-1,P-195-200

10. Anbarasi M., Praveen Kumar S., Various online marketing and promotions strategies to improve the validation towards the organic products in the pharmaceutical sectors,2019,Indian Journal of Public Health Research and Development,V-10,I-1,P-263-269

11. Loganathan R., Praveen Kumar S.,Grievance handling a key factor for solving issues of employees in an organization,2014,International Journal of Applied Engineering Research,V-9,I-22,P-7483-7491

12. Loganathan R., Praveen Kumar S.,Study on preference of private label brands in super and Hypermarkets,2014,International Journal of Applied Engineering Research,V-9,I-22,P-7327-7335

13. Smitha M., Praveen Kumar S.,Understanding stress and its managementamong the nurses in Chennai city,2014,International Journal of Applied Engineering Research,V-9,I-22,P-7560-7565

14. Kerinab Beenu G.H., Praveen Kumar S.,A study on the investment behavior of Chennai investors in mutual fund schemes,2014,International Journal of Applied Engineering Research,V-9,I-22,P-7520-7525

15. Loganathan R., Praveen Kumar S.,Retention strategies key for organizational productivity,2014,International Journal of Applied Engineering Research,V-9,I-22,P-7443-7447

16. Pavithra J., Ganesan M., Brindha G.,State wise analysis of microfinance sector in India,2016,International Journal of Pharmacy and Technology,V-8,I-4,P-23417-23432

17. Pavithra J., Ganesan M.,A comparative study on microfinance in India and abroad,2016,International Journal of Applied Business and Economic Research,V-14,I-8,P-5471-5476

18. Pavithra J., Ganesan M.,A study on awareness and impact of micro-financial schemes,2016,International Journal of Applied Business and Economic Research,V-14,I-8,P-5449-5460

19. Senthilmurugan P., Pavithra J.,Consumer preference towards organised retailing with reference to Big Bazaar,2014,International Journal of Applied Engineering Research,V-9,I-22,P-7469-7475

20. Senthilmurugan P., Pavithra J.,Implication of social media marketing in growing healthcare industry,2014,International Journal of Applied Engineering Research,V-9,I-22,P-7448-7456

21. Loganathan R., Pavithra J.,Consumer perception towards private label brand over other brands in super markets and hypermarkets,2014,International Journal of Applied Engineering Research,V-9,I-22,P-7355-7360
22. Kerinab Beenu G., Pavithra J.,Tradeâ€"off between liquidity and profitability in logistics industry,2014,International Journal of Applied Engineering Research,V-9,I-22,P-7398-7401

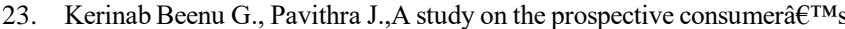
perception towards utility cars in Chennai city,2014,International Journal of Applied Engineering Research,V-9,I-22,P-7526-7531

24. Pavithra J., Dilli Babu P., Ambuli T.V.,A study on budgetary control at Maruti Service Masters, Chennai,2014,International Journal of Applied Business and Economic Research,V-12,I-2,P-151-161

25. Pavithra J., Dilli Babu P., Ambuli T.V.,A study on customer satisfaction of retro Garments Pvt Ltd, Chennai,2014,International Journal of Applied Business and Economic Research,V-12,I-2,P-381-391

26. Kerinab Beenu G.H., Pavithra J., Senthilmurugan P.,A study on the influence of promotional activities for TATA ARIA among consumers in Chennai,2014,International Journal of Applied Engineering Research,V-9,I-22,P-7572-7578

27. Vijayaragavan S.P.,An investigative expert that's general FBG sensors,International Journal of Mechanical Engineering and Technology,V-8,I-8,PP-1500-1505,Y-2017

28. Vijayaragavan S.P.,Equalization routing protocol for $\mathrm{Wi}-\mathrm{Fi}$ sensor strategy,International Journal of Mechanical Engineering and Technology,V-8,I-8,PP-1662-1666,Y-2017

29. Karthik B., Kiran Kumar T.V.U., Vijayaragavan P., Bharath Kumaran E.,Design of a digital PLL using 0.35 1 1/4m CMOS technology,Middle East Journal of Scientific Research,V-18,I-12,PP-1803-1806,Y-2013

30. Kanniga E., Selvaramarathnam K., Sundararajan M.,Kandigital bike operating system,Middle - East Journal of Scientific Research,V

31. Jasmin M., Vigneshwaran T., Beulah Hemalatha S.,Design of power aware on chip embedded memory based FSM encoding in FPGA,International Journal of Applied Engineering Research,V-10,I-2,PP-4487-4496,Y-2015

32. Jasmin M.,Optimization techniques for low power VLSI circuits,Middle East Journal of Scientific Research,V-20,I-9,PP-1082-1087,Y-2014

33. Jasmin M., Vigneswaran T.,Fuzzy controller for error control of on - Chip communication,2017 International Conference on Algorithms, Methodology, Models and Applications in Emerging Technologies, ICAMMAET 2017,V-2017-January,I-,PP-1-5,Y-2017

\section{AUTHORS PROFILE}

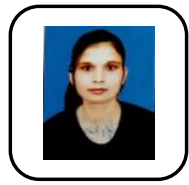

Pallavi Kumari, Student, Department of Management Studies, Bharath Institute of Higher Education and Research, Chennai, India

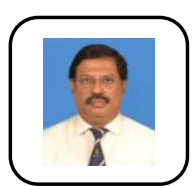

Ravimohan, Associate Professor, Department of Management Studies, Bharath Institute of Higher Education and Research, Chennai, India

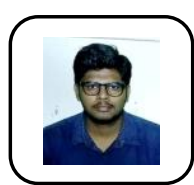

C. Kireeti Reddy, Student, Department of Management Studies, Bharath Institute of Higher Education and Research, Chennai, India 